\title{
Ethno-tourism in Russian Regions: Challenges and Prospects for Development
}

\author{
By Anna N. Polukhina*
}

This paper aims to shed light on the prospects of ethno-tourism cluster development in Russian regions. The methodology provided in the paper is applicable for the study of cluster approaches in tourism. The focus here is on good practices of ethno-clusters in tourism in Russian regions. In order to achieve this analysis, specific methods are used, including: system and comparative analysis, assessment of the resources and capacities of regions, administrative diagnostics, expert estimates, in-depth interviews, and social and psychological researches. The main results of this study show that the challenges and prospects for ethno-tourism development are defined and supported by the Mari El case study. The factors influencing ethno-tourism development are the tourism potential of the region, the attitude of local authorities towards tourism, the availability of necessary infrastructure and qualified personnel. The conditions facilitating the success of tourism cluster development are also analyzed. Firstly, this requires development of the target program for tourism with an emphasis on ethno-tourism at the level of local authorities; secondly, investment in tourism infrastructure development is necessary. This research is of practical importance for the modernization of domestic tourism programs in order to boost the regional economy.

Keywords: ethno-tourism, ethno-tourism clusters, regional tourism, ethno-tourism resources.

\section{Introduction}

The Russian Federation entered the Federal Target Program on Tourism Development until 2018. It was initiated by the Federal Target Program "Development of Incoming and Outgoing Tourism in the Russian Federation" between 2011-2016, which was approved by Regulation No. 644 of the Russian Federation (2 August 2011). The main aim of the program is the commercialization of Russian tourist products on the national and international markets, via the development of the tourist and recreational complex in Russia and improvement of the quality of tourist services. The cluster approach is regarded as the basis for this change. This approach concentrates on a single lot the enterprises and organizations involved in development, production and sale of tourist products, as well as related businesses.

In the framework of the program, recreational and automobile tourism clusters in the 25 most prospective regions have been planned. Altogether, seven major tourist destinations were selected: the Silver Ring of Russia, the Golden Ring of Russia, South Russia, Big Volga, Siberia, the Baikal Region and the Far East. The clusters presume the construction of modern and comfortable

*Professor of Service and Tourism Department, Doctor of Economic Sciences, Department of Service and Tourism, Volga State University of Technology, Russia. 
hotels, camping sites, cafes and restaurants, sports, recreational and trading centers, parking lots and other infrastructure units. The total financing of the Federal Target Program is 332 billion rubles. The share of the budget coming from federal funds is $28 \%$; the local funds share is $7.5 \%$ of the total amount. The major financing is expected to come from private investors based on a competition between investment projects. The federal budget will partly cover investors' expenses in credits and loans. It is planned that the regions shall be partly subsidized (co-financing scheme) for the construction of infrastructure.

Nowadays, there is a hierarchy of tourist regions in terms of scale: tourism and recreation zone, tourist macro-region, tourist meso-region, tourist neighbourhoods, and tourist objects. In different countries, the potential tourist regions vary in terms of tourism attraction. Thus, attraction of the region may be obtained due to a number of factors: nature, culture and history, society and economy, ethnic-confession or religious factors.

The record shows that there is a close link between the tourist regions of various levels and tourism and recreation complexes. By the latter, we mean a complex establishment that includes healthcare and recreational institutions, servicing institutions and related industries (retail enterprises and catering facilities, social, cultural and sports institutions, sightseeing objects, traffic network, souvenir production, etc.). Thus, Aleksandrova (2003) argues that the most typical features of tourism are a vastness of interconnected ties, fragmented structure, dominance of small and middle-sized businesses, and a non-material character of tourist products. These aspects, as well as some other factors, make the application of a cluster approach desirable for tourism development. At the moment, the urge for development and the principles for tourism clusters establishment in Russia are approved by the government.

In many Russian regions, there are large-scale ethno-tourism projects. In order to capitalize on the ethno-cultural potential, it is very important to create recognizable and attractive regional brands. The major problem in Russia nowadays is that although regions tend to create locally recognizable brands, they cannot often link them into a cluster and promote them in a proper way (Chizhova, 2011). Mari El Republic may be considered a potential regional tourist cluster. The unique character of the Mari territory in terms of history, culture and ecology can surely make the place a desirable tourist destination. In other words, the regional tourism cluster should be based on a unified concept. We believe that the best unified concept in this context is ethno-tourism and its preservation of the traditional religious belief of Mari people - i.e. paganism that should act as a basis for tourism development in the region.

Ethnographic tourism (ethno-tourism) is defined as a type of cognitive tourism aimed at visiting ethnographic objects in order to learn about culture, architecture, traditions, and ethnos that are living or used to live on the visited territory. Ethnic differences, uniqueness of place and culture are more often becoming the local tourism band in the world practice. Such old crafts as winemaking, woven work, fishing and pottery have become additional attractions for tourists. This is one of the ways through which new tourist destinations are created, for example, in France, Spain and some Scandinavian countries. Shifts 
in tourist preferences lead to the development of a new model of tourism, which involves the ethno-tourism landscape, preserving the traditional lifestyle with all its characteristic features.

Another good example of ethno-tourism development is from Canada, which focused on tourism as a priority of economic development. In this country, tourism helps the government solve the problems of aboriginal organizations and northern territories, while aboriginal people get the chance to restore and preserve their cultural traditions. The aboriginal tourism industry in Canada is presently estimated at \$596 million, employing 14,000-16,000 aboriginal people (Report ATAC, 2015). Businesses include aboriginal tourist trails, hotels and camping sites, restaurants with the national cuisine in Indian reserve lands, combined clusters, cultural centres, interactive museums-villages, and totemic souvenirs (Chizhova, 2011).

This paper is organized in six sections, including this introduction. The next section presents some of the international literature and discusses the methodology of research. Section three looks at the characteristics of successful ethno-tourism clusters in Russian regions. The next two sections of the paper look at two case studies: the Volga-Kama territory and the Mari El republic. The last section concludes.

\section{Selective Literature Review and Research Methodology}

There are a lot of definitions of a cluster and accordingly a wide experience of cluster economy development in many countries. The originator of the cluster theory, Michael Porter, referred to clusters mainly in industry and defined them as "geographic concentrations of interconnected companies, specialized suppliers, service providers, firms in related industries, and associated institutions (universities, standards agencies, and trade associations) in particular fields that compete but also cooperate" (Porter, 1998).

He emphasized that successful cluster establishment requires a sustainable development strategy as a prerequisite. In his view, clusters represent an organizational form of consolidated efforts of all stakeholders, aimed at gaining competitive advancements in economy. The major goal of clustering is the opportunity for businesses and the region to develop, based on a long term 5-10 year strategy (Porter, 2001).

A tourism cluster is an important innovative element of the regional development and economic growth. There are works on tourism that study the dependence of tourism clusters on the boost of a regional economy. In order to support the concept, we should refer to Nordin's work on tourism clustering and innovation as a tool for economic growth and development (Nordin, 2003). In this research, she describes the successful experiences of clustering in South Africa, Australia and New Zealand. The Croatian researcher Moric views clusters as the development factor for competitive regional tourism (Moric, 2013). Ferreira (2010) assumes that all the services that can be provided to a tourist should be included in the tourism cluster. 
In terms of our work, we refer to regional tourism clusters research carried out by Jackson and Murphy in the context of Australia. The authors argue that tourism clusters are geographical concentrations of state and private companies and institutions interconnected in tourism activities. At the regional level, this linking is very important as it increases the number of companies directly involved in the tourist business (Jackson, Murphy, 2006).

Beni (2003) holds a different opinion on the tourism cluster by narrowing it down to a set of tourist attractions concentrated on the same geographical area. This includes a complex of constructions, goods and services, as well as management coordination over these firms and companies.

We also share the point of view of Romanian tourist cluster researchers Negruşa and Toader (2012), who argued that one of the most important aspects of cluster development in tourism is the appropriate combination of state politics and private business strategies. These should operate together in order to meet customer needs and form sustainable attraction to a certain region. In addition, any tourist cluster should offer a tourist product tailored for the definite market.

Rodrigues (2003) views the relations between companies and institutions in the tourist cluster from two different aspects: horizontal ties and vertical ties. Horizontal ties establish strategic alliances in which there may be two types of agreements. On the one hand, agreements between companies offering similar goods or uniform business activities, such as accommodation, entertainment, transport and catering, may cooperate. On the other hand, agreements can be drawn between companies offering diverse tourist products and forming different components of a complex tourist product or service.

Vertical ties create strategic networks based on unilateral customer-supplier relations and money-product exchanges. These occur when one partner is a supplier of a necessary good or service and the other is ready to remunerate for this good or service on a contractual basis.

According to Rodrigues, a tourist cluster represents a group of companies and institutions producing a tourist product or a group of products. These companies and institutions are geographically concentrated and feature vertical ties (company chains, producing tourist product) and horizontal ties (including industry, legal support and information exchange).

According to Aleksandrova (2007), the experience proves the efficiency of cluster development in tourism. One of the peculiar features of tourism clusters is the necessity to establish technological links (mainly business links) between enterprises and economy sectors, which are involved in both production and selling tourism products and services. It is necessary to create a favorable environment for the promotion of tourism and recreational potential in the region. Tourism clusters are established based on key tourism and recreational resources found in the region. A tourism cluster's stakeholders commonly include enterprises and organizations involved in both the production and sale of tourism products and services. It is deemed beneficial for the development of the region to involve such stakeholders as representatives of authorities, research institutions, educational institutions, professional communities, public 
leaders, etc. A tourism cluster can be established at both the local (municipal) and regional levels. There are also examples of interregional tourism clusters (Shabalina 2012).

The concept of ethno-tourism in science is relatively new; thus, detailed methodological approaches are still in the development stage. In our research, we refer to the practical description of ethno-tourism. Ethno-tourism or ethnographic tourism is based on the interest tourists have in the authentic life of peoples, their traditions, riots, crafts and culture. In the contemporary unified world a person seeks self-identity, tries to find and study his/her ethnic origin in order to feel somewhat special, having long history and personal cultural traditions.

Awareness of other cultures and ethnic features allows us to create a better, clearer picture of the multifaceted world of peoples and nations, who are all unique in their identity. Ethno-tourism promotes closer links between the representatives of the peoples, both visitors and residents, and facilitates input of their culture in the world cultural heritage.

In this respect, Russia has almost unlimited potential for the development of all types of tourism, including ethnographic. Russia has rich potential for the development of all kinds of tourism, including ethno-tourism. There is everything necessary for this purpose: vast territories, rich historical and cultural heritage. The history of Russia was influenced by the Vikings, early Slavs, Mongol-Tatars, Cumans, Scythians, Swedes, Teutons, Greeks, Genoese and other peoples. Our ancestors have inherited their appearance, religion, culture, language and traditions. All this stimulates the development of ethnographic tourism by making contemporary Russian people and visitors from other countries mutually interesting.

In order to capitalize on this ethno-cultural potential, it is very important to create recognizable and attractive regional brands. The major problem in Russia nowadays is that although regions tend to create locally recognizable brands, they cannot often join them into a cluster and promote them in a proper way. So far, it is challenging to promote brands from the local level to the regional one, from the regional to interregional, from the interregional to the federal and from the federal to the world. This requires a systems approach to the branding issues on the federal and regional levels (Chizhova, 2011).

In 2011, in the framework of the exhibition "Treasures of the North-2011" that took place in All-Russia exhibition centre in Moscow, there was a conference organized and devoted to ethnographic tourism as a way to preserve and recover ethno-cultural heritage. According to the head of the Department of domestic tourism development, Mr. Sirchenko, the conference pursued two major goals: the development of ethnographic tourism in the country with 180 nations and the demonstration of its potential to regional authorities, tour operators and the mass media. All the conference participants emphasized their growing interest in ethnic routes, which is also proved by the survey carried out by the Federal Agency for Tourism (Rosturism). Such tours are attractive for $88 \%$ of the respondents; however, $91 \%$ of the respondents stated that there is insufficient information and promotion of these tours (first of all, there are not enough 
ethnographic guide books) (Timofeev, 2011).

The focus of this analysis must therefore be to inspire and develop good practices of ethno-clusters in tourism in Russian regions. In order to achieve this analysis, specific methods are used, including: system and comparative analysis, assessment of the resources and capacities of regions, administrative diagnostics, expert estimates, in-depth interviews, and social and psychological researches.

\section{Characteristics of Successful Ethno-tourism Clusters in Russian Regions}

Ethno-tourism development depends on a number of factors: tourism potential of the region, potential of the area, attitudes of the local community and local authorities towards this kind of tourism, availability of the necessary infrastructure and personnel qualification. In places where the efforts align, there are obvious positive results. The best developed sites in terms of ethnotourism are located in Yamalo-Nenets and Khanty-Mansiysk Autonomous Districts of Tyumen Region, Krasnodar and Stavropol Territories in Russia.

An ethnic direction for the Russian tourism is not a new issue. For example, the ethnographic open-air museum Torum Maa in Khanty-Mansiysk was founded in 1987. It is a popular place for both local residents and tourists (Timofeev, 2011).

There are other examples of making ethnographic complexes and trails attractive for tourists. One of the positive examples is a national village of the Russian North "Pozharishe" Nyuksensky District of the Vologda region. The place had over 20,000 visitors a year and was considered the best regional tourist project of 2009. Village Martynovo of Myshkinsky District in Yaroslavskaya Region is also a very popular tourist attraction. The place is considered the center of the colorful sub ethnos of the Russian people called "katskari". Quite a number of regions have projects that are connected with ethnic tourism in a variety of ways.

The program for tourism development in Pskov Region requires large scale investments into the tourist infrastructure of Sigovo village in Izbor Region, as well as including this village into most tourist trails. There is also a minority of Seto people (Orthodox Christians of Estonian nationality) residing in the area. Finally, not very far from Moscow, close to Borovsk there is one of the largest ethnographic parks in Russia called Ethnomir.

In Krasnodar Territory due to ethno-tourism development all the interested people can get to know their national culture, as well as immerse themselves into the traditions of other Kuban peoples. In the village called Gai Kodzor in Krasnodar Territory, there is a cultural Armenian center "Arin Berd", which contains materials and guides to tell the visitors about the history and culture of one of the largest diasporas in Kuban. The village looks like a fortress with wrought iron gates guarded by ancient warriors. The centre of the village preserves Armenian style in everything; there are large paintings on the walls, each demonstrating an important moment in the life of Armenia. 
In Anapa region there is another unique park called Dobrodea. The park includes the ethnographic exposition "Kazache podvorie" (Cossack habitation), which is represented as a Cossack museum telling the visitors about the history of Cossacks in the Kuban. The folk music group adds flavor to the visit. The visitors to the place get a chance to see a Cossack hut, Cossack traditional oven and poultry house. The local tavern offers a wide range of the Kuban cuisine.

In the Crimean region of Krasnodarsky Territory there is an ethnic cultural and entertainment center "Caucasus Legends", where the visitors learn about Circassian customs and folklore, taste the national dishes. Every visitor can do crafts, take a hiking or horseback riding tour, be involved in health promoting events, fishing, and cattle patting in addition to traditional sightseeing or learning national traditions. The visitors get a chance to be active participants in traditional holidays and rituals, try the national cuisine or buy traditional household items as souvenirs.

\section{Establishing Ethno-tourism Clusters in Volga-Kama Territory}

The Perm Territory is a significantly large area inhabited by numerous nations. At the end of 2009, a tour operator Kumir (Kungur) in cooperation with the excursion agency Klio (Perm) developed a new cycle of day tours under the umbrella concept "Every village has something different to offer". The key idea of the project is to introduce the lives and authentic culture of indigenous peoples of the Kama regions to the residents and visitors, thus making the ethno-cultural identity of the region a tourist attraction. In Byrma village the visitors were welcomed with bread and salt and Chak Chak (a sweet dessert, made of honey and pastry). The two dishes are the traditional welcome symbols of the Russian and Tatar peoples. The visitors got to know the music culture, songs in Russian and Tatar languages and traditional national dances. In the village mosque beautifully decorated with carpets and homespun cloths, the mullah told the visitors about the religious life in the village. The visitors could purchase local craft goods: knitted figured shawls, birch bark and other goods made of natural materials. Visit to Byrma village finished with a collective dinner served in a peasant Tatar house. The hosts invited the visitors to take a look at the estate yard.

Another ethnographic route is a cognitive tour "Visiting Sylvenskie Mari people". This tour combines the elements of rural, ethnographic and environmental tourism. Sylvenskie Mari people belong to minor nations residing in the Perm region. They live mainly in three villages of Suksunsky region Baskovo, Ivankovo and Tebenyaki. Once tourists select this route, they learn about the natural and economic peculiarities of the Suksun region, as well as about the history of Suksun enterprise and famous Russian people - V. Tatishchev, A. Demidov, etc. The major part of the tour is devoted to the traditions of a Mari village. Sylvenskie Mari people, originally coming from central Russia, have preserved their identity and national characteristic features. The visitors immerse themselves into the atmosphere of a national holiday for three or four hours. The ceremonies organized for the visitors include "Meeting guests", "worshiping a 
birch tree", "By the spring", singing songs and making talks in the Mari language, learning about the daily routines of Mari people, interior decoration of the house, souvenirs and taking pictures in traditional costumes. The program also includes learning about various household activities.

However, one of the most famous ethno-tourism events in the Perm Territory is the festival of ethno-futuristic Finno-Ugric culture KamWA, which traditionally finishes on the first Sunday of August in the historic and ethnographic nature reserve "Khokhlovka". It is the holiday of the new harvest and a grand concert which attracts thousands of people from all over the territory. World famous music groups often participate in KamWA. In 2010, KamWA was first introduced as an independent tourism product. Tourist programs lasted from one to five days and included accommodation, catering, transfers, guided tours, festival events, excursions, museums and introductions to new issues in Perm tourism. The experts at the festival specially noted the innovative character of the product and quality service for the participants and tourists.

In the Komi Republic close to Syktyvkar, there is the first stage of the large Finno-Ugric ethno-cultural park. The total area of the park is 456 ha with a favourable location on the river Sysole, in Syktyvdinsky region, $55 \mathrm{~km}$ to the south of Syktyvcar, very close to the federal road Syktyvkar-Kirov. There is an old village $\mathrm{Yb}$ nearby. The village dates back to the $16^{\text {th }}$ century and is considered a sacred place, due to the fact that the reverend Stephan of Perm, also known as the Christianizer of Zyryan (obsolete name of the Komi people) and Companion of Sergius of Radonezh. There are 12 revered healing springs in proximity to the village. The area where the park is being established is one of the most ecologically clean. Its unofficial name is the "green lungs of Europe".

The first stage of the park, as envisioned by the architects, is bound to bear the cultural and cognitive meaning. Its architecture and conceptual centre is a twostorey concert and exhibition complex called "Finnougorie" and including a large concert and business center. Next to the centre, there are ethnic villages of FinnoUgric peoples, summer theatre, the only museum of Finno-Ugric toy in the world, classrooms for different workshops, children's recreational area, ground for traditional riots and the park of Finno-Ugric sculpture. The first stage of the project also includes a mini-hotel in Zyransky style, capable to accommodate 50 visitors and a restaurant of Finno-Ugric cuisine.

The Republic of Tatarstan was among the first Russian regions (after Moscow and Saint Petersburg) which started investing into its image as an ethnotourism region from 1990s. The Republic has developed such an image that allows combining the elements of the real history and the myth, traditional ethnic culture and contemporary urban environment. From the point of view of western perception, it is a unique region in which Islamic and Orthodox cultures peacefully cohabit, and mosques are located next to Orthodox churches. For a Russian tourist, it is a very comfortable European region, rich in historical and cultural values.

Thus, the Kazan Kremlin is considered the monument of the Khan's period, even though only ground it from that time; the mosque itself has been erected on the ancient ground place. Another example is the watchtower of Soyumbike. There is a beautiful legend around this place. The real story is Bulgar, Sviyazhsk 
(Chizhova, 2011). A good example of the national cuisine capitalization is the supermarket network Bekhetle, where they sell traditional Tatar products together with product lines from the ordinary supermarket.

In our research, we referred to Mordovia experience of Ethno-tourism development. The major rivers of the Republic are Sura, Moksha and Insara, which are not the desired tourist destinations. Never the less, tourism is considered one of the priority directions for the economic development in the Republic. In expert opinion, the most prospective types of recreation for the Republic are ethnic, cultural and historic, business and professional tourism.

There are over a thousand historic and cultural monuments on the territory of the Republic, 52 of which are acknowledged at the federal level. Putting into practice the program for the tourism development is bound to increase incoming tourists by $10 \%$. It is estimated that after the program is implemented to the full extent, the annual tourist arrivals will reach 80,000. In the framework of the program they developed the first tourist trail "Erzya i Erzyane," which involves getting acquainted with the works of a famous sculptor and the traditions of local people. The trail includes a visit to an Erzyan village where the visitors can get the flavor of everyday life, culture and traditions of the Erzyan people.

There are currently seven centres of national culture working in the territory of the Republic. In these centres the visitors can learn about everyday life, crafts, clothes and riots of Mordovia people. Such centres are especially important for domestic intraregional tourism development. They can attract tourists through organizing holidays and festivals in the centre of national culture, such as the festival of national cultures Shumbrat or Finno-Ugria.

The key challenge for tourism development in Mordovia, like in many other regions, is the lack of infrastructure. First of all, there are not enough hotels to accommodate all the visitors. Finno-Ugric festivals attract thousands of people. Without proper accommodation they have to stay overnight in dormitories, tourist or recreational camps.

\section{Challenges of Tourism Cluster Development: The Mari El Case Study}

Mari El Republic may be considered a potential regional tourist cluster. The unique character of the Mari territory in terms of history, culture and ecology can surely attract tourists. Our opinion is that ethno-tourism (preserving the traditional religion of the Mari people, paganism) should become the central idea for the Mari El Republic, which should define the program of tourism development in the region.

There are ethno-cultural monuments in almost every region of Mari El Republic. The Gornomariysky region (Mountainous Mari Region) and Kozmodemyansk are famous for their historical potential and tourist resources, particularly for cognitive tourism. There is evidence that these were Mari people from this area, who helped the Russian Tsar Ivan the Terrible in his famous battle in Kazan to annex lands to the Russian state. Emelian Pugachev (Russian peasant leader, head of the peasant rebellion of 1773-74) passed this place together with 
his troops. There is well-known evidence to this fact, such as Pugachev's oak. The town's wooden architecture was erected in the 19th century and still appeals to tourists. There are also a lot of ancient archeological objects in the region.

In the Morkinsky region, there is an ethnographic Mari village constructed by enthusiastic people without any external financial support. In summer time it becomes an attractive tourist destination, especially popular with tourists from Finland. In Kilemarsky region of the Republic there is a program "Development of local social and economic initiatives using the potential of specially protected areas and Environmental Non-Commercial Organizations, funded by the TACIS project. In future it is planned to construct a number of ethno-tourism complexes and rural guest houses around Kugu Kokshan nature reserve, located in the region. We should state that for the past 5 years the most part of the project was not implemented.

We believe there is an opportunity to significantly develop the potential of ethnographic tourism resources in Mari El by introducing myths of Mari and Russian peoples, contemporary animation experience.

We shall refer to the use of Mari mythology for innovative product development. For example, one of the most colourful solar holidays for Mari people is called Surem (Сўрем). According to the literature, on this day people exiled evil spirits from the village. In order to achieve this they prayed and offered sacrifice (A. Fux, 1840). It is worthwhile mentioning the following elements of the holiday: prays to the main God Yumo, putting up fires, into which people threw all the leftover food, telling exorcising prayers on health, happiness and wealth and participating in the horse holiday. The main idea of the holiday is to drive out demons.

In the $16^{\text {th }}-19^{\text {th }}$ centuries Russian people had a holiday of Ivana Kupaly (the day of St. John the Baptist), usually celebrated on the day of summer solstice. Nowadays the elements of this holiday are also used for animated performances and tourism products. We believe, that based on the Mari ethnographic materials, it is possible to create an interesting and attractive tourist product. The storyline used for the holiday includes a number of magic elements that provide flexibility in terms of promotion and stirs the participants' imagination.

However, there are a lot of obstacles hindering ethno-tourism (aboriginal tourism) development. It is quite a common situation, when the most interesting peoples in terms of an ethnographic context live in remote regions of the country where there are no accommodation facilities or decent road systems. Even when these are present, the place can be visited only several months per year. Another factor hindering tourism development is the contradictions in legislation on both federal and regional levels. The author states that there is one more important obstacle hindering regional tourism development: some local people, the middle class in particular, demonstrate their negative attitude towards the idea of ethnographic tourism. They feel that it threatens their national identity and dishallows the national culture and people's spirit. We believe that the concept of tourism development in Mari El Republic should be developed based on the local authentic culture, thus, it would be unwise to concentrate on one cultural tradition only, be it Mari, Tatar or Russian, as in this area we face a multiculturalism model 
that has been developed for centuries in the Volga region. It is necessary to acknowledge the mutual interrelation and impact of cultures and myths of these peoples onto each other. In addition, it is necessary to mention that contemporary tourism is aimed at cognition of new and interesting facts rather than scientific research therefore it is very important to properly interpret the mythological material, organize and promote the tour.

It is possible to create a unique rural hotel in a Russian village (or Mari or Tatar village) to immerse the visitors into everyday life of the people, on condition that the tourists are properly informed on such opportunities, otherwise, tourism development is going to be a failure.

The model of ethno-tourism development includes a number of constituent elements, such as certification of the regions in the Republic based on the presence of ethnographic monuments, real business-ideas and projects, search of investors with the focus on tourism infrastructure including accommodation, catering and main transport routes.

\section{Conclusions}

The use of the ethno-tourism concept for regional tourism development in the Volga-Kama region is sure to make the region more attractive for investors on the one hand and stir interest to authentic culture of people residing in the area, on the other. However, in order to achieve success in using the historian and cultural objects for tourism, it is deemed necessary to develop a target program of tourism development on the level of regional authorities with the focus on ethno-tourism; more carefully develop the necessary infrastructure. We believe that in order to create an ethno-tourism cluster in any Russian region, including the Mari El Republic, it is first of all necessary to define the key concept. It may be either observance of everyday life of a traditional Mari (Perm, Komi) village, but unless the local residents are willing to be involved in this program, it will not bring sustainable income.

Thus, there should be cooperation between the local entrepreneurs, investors and local authorities. One or several large-scale tourist operators should also be involved in order to promote the product on the national tourism market. Establishing a tourism cluster in the region is bound to significantly facilitate regional tourism development.

\section{References}

Aleksandrova AY (2003) International tourism, 114p., in Russian.

Aleksandrova AY (2007) Tourism clusters: contents, boarders, mechanism of functioning // Contemporary problems of service and tourism. - 2007. - No1. - P. 51 - 61.

Beni M (2003) Globalização do Turismo: Megatendências do Sector e a Realidade Brasileira

Chizhova O (2011) The potential of Russian territories in ethno-tourism is huge, 1 July, 2015, available at http://www.ratanews.ru/news/news_30092011_3.stm, in Russian. 
Ethno-tourism. Available at: http://www.visitperm.ru/info/interesting/ethno/

Ethnographic tourism (ethno-tourism), available at http://www.rusotdih.ru/publicatio ns/show15/, in Russian.

Federal Target Program (2011). Development of Incoming and Outgoing Tourism in the Russian Federation Between 2011-2018), in Russian.

Ferreira M (2010) Regional competitiveness of a tourism cluster: a conceptual model proposal // Tourism \& Management Studies. 2010. P. 37-51.

Jackson J, Murphy P (2006) Clusters in regional tourism. An Australian Case. Annals of Tourism Research (Vol. 33, No. 4.) pp. 1018-1035.

Kachniewska M (2013) Towards the Definition of a Tourism Cluster // Journal of Entrepreneurship Management and Innovation (JEMI), Volume 9, Issue 1, 2013: P. 33-56.

Mazilu M (2013) Tourism - Innovation for Sustainable Tourism Cluster model // International journal of energy and environment. Issue 1, Volume 7, 2013. P. 19-26.

Moric I (2013) Clusters as a Factor of Rural Tourism Competitiveness: Montenegro Experiences // Business Systems Research. Vol. 4 No. 2. December 2013 p. 94-107.

Negruşa AL, Toader V (2012) Networks and cluster, ways for developing tourism sector in Romania: $2^{\text {nd }}$ AHTMM Conference. - Greece

Nordin S (2003) Tourism clustering and innovation: paths to economic growth and development. Osrtersund: European Tourism Research Institute, 2003. 90 p.

Novell M, Schmitz B, Spencer T (2006) Networks, Clusters and Innovation in Tourism: the UK Experience // Tourism Management. Vol. 27, 2006. P. 1141-1152.

Report ATAC (2015) Available at http://aboriginalcanada.ca/corporate/wp-content/uploa ds/2015/04/REPORT-ATAC-Ntl-Ab-Tsm-Research-2015-April-FINAL.pdf)

Rodrigues AB (2003) Turismo rural: praticas e perspectivas. - Sao Paulo: Contexto

Porter M (2001) Competition M. Williams Publishing house, 495p., in Russian.

Porter M (2001) On Competition. Boston, Harvard Business School Press.

Salted ears, zyryane and erzyane - Finno-Ugric ethno-tourism on the march. - Available at http://finugor.ru/node/22336, in Russian.

Shabalina NV (2012) Introduction into tourist cauterization. Available at http://bzm.su/ articles/article-05, in Russian.

Székely V (2011) Tourism clusters as a tool for the improvement of rural competitiveness: first experiences from Slovakia // Discussion papers 2011. Special issue - aspects of localities http://discussionpapers.rkk.hu/index.php/DP/article/view/2472

Timofeev Y (2011) Russian regions are just at the beginning of their way in ethno-tourism development, 1 July, 2011, available at http://www.ratanews.ru/news/news_6052011 _1.stm, in Russian. 